\title{
Yavaş Şehirlerde Sosyal Değişme ve Yaşam Kalitesi İlişskisi Üzerine Bir Araştırma: Gerze Örneğgi
}

\author{
A Study on the Relationship Between Social Change and Quality of Life in Slow \\ Cities: The Case of Gerze
}

\author{
Olcay ÖZIŞIK YAPICI* \\ Safak ÜNÜVAR**
}

\begin{abstract}
$\ddot{O} Z$
Dünyada ve ülkemizde her geçen gün yavaş şehirlerin saylsı artış göstermektedir. Günümüzde insanlar alternatif tatil türlerine katılmayı tercih etmektedir. Alternatif tatil rotaları arasında yavaş şehirler de yer almaktadır. Doğa ile içiçe, yöresel lezzetlerin tadıldığ ve gürültüden uzak, kimliklerinin korunduğu yerler olarak yavaş şehirler karşımıza çıkmaktadır. Türkiye'de yavaş şehirlerin turistik destinasyon olarak kullanılmasında lider konumda Seferihisar yer almaktadır. Türkiye'deki ilk yavaşs şehir olma özelliğine sahip olan Seferihisar yavaş şehir kimliğini etkin bir şekilde kullanarak turizmden kazanç sağlamaktadır. Yavaş şehirler zamanla turistlerin yoğun olma nedeninden ötürü bir takım olumlu ve olumsuz değişmelere maruz kalabilmektedir. Özellikle sosyal değişmelerin yavaşş̧ehirlerde olumlu yönde yaşanmasl, yerel halkın yaşam kalitesini olumlu yönde etkileyebilir. Yaşam kalitesinin gerek toplumsal gerekse bireysel olarak yükselmesi ile birlikte, yerel halkn yavaş şehire yönelik tutumu da olumlu yönde olabilecektir. Bu çalışma, Türkiye'deki yavaş şehirlerden biri olan Sinop'un Gerze ilçesinde sosyal değişmenin yaşam kalitesi algısı üzerinde etkilerinin olup olmadığını belirlemek amacıyla yapılmıştır. Gerze yerel halkına yönelik anket uygulanmış ve 410 tanesi değerlendirmeye uygun bulunmuştur. Elde edilen sonuçlara göre sosyal değişmenin toplumsal ve bireysel yaşam kalitesi üzerinde istatiksel olarak anlamlı ve pozitif etkileri söz konusudur.
\end{abstract}

\section{ANAHTAR KELIMELER}

Turizm, Yavaş Şehir, Sosyal Değişme, Yaşam Kalitesi, Gerze

\begin{abstract}
The number of slow cities is increasing day by day in the world and in our country. Today, people prefer to participate in alternative holiday types. Alternative holiday routes include slow cities. Slow cities come together with nature as places where local flavors are tasted and away from noise and where their identities are preserved. Slow city in Turkey as a leader in the use of tourist destination located in Seferihisar. The first slow city in Turkey, having the distinction of being slow city Seferihisar using the identity effectively providing earnings from tourism. Slow cities may be exposed to a number of positive and negative changes due to the intensity of tourists over time. Especially, social changes in positive cities in a slow way may affect the quality of life of the local people positively. With the increase in the quality of life both socially and individually, the attitude of the local people towards the slow city may also be positive. This study is one of the city's Gerz slowly changing social perceptions of the quality of life in the town of Sinop in Turkey, and was conducted to determine whether the impact on the local population's attitude towards the slow city. A survey was conducted for the local people of Gerze and 410 were found suitable for evaluation. According to the results obtained, social change has statistically significant and positive effects on the quality of social and individual life.
\end{abstract}

\section{KEYWORDS}

Tourism, Cittaslow, Social Change, Life Quality, Gerze

\begin{tabular}{|c|c|c|}
\hline \multicolumn{2}{|r|}{$\begin{array}{c}\text { Makale Geliş Tarihi / Submission Date } \\
\text { 05.08.2020 }\end{array}$} & $\begin{array}{c}\text { Makale Kabul Tarihi / Date of Acceptance } \\
30.08 .2020\end{array}$ \\
\hline Attf & $\begin{array}{l}\text { Özışık Yapıc1, O. ve Ünüvar, Ş. (202 } \\
\text { Araştırma: Gerze Örneği. Selçuk Ünive }\end{array}$ & $\begin{array}{l}\text { syal Değişme ve Yaşam Kalitesi İlişkisi Üzerine Bir } \\
\text { Meslek Yüksekokulu Dergisi, } 23 \text { (2), 565-576. }\end{array}$ \\
\hline
\end{tabular}

\footnotetext{
${ }^{1}$ Bu çalışma 03.03.2020 tarihinde Selçuk Üniversitesi Sosyal Bilimler Enstitüsü tarafindan kabul edilen 'Sosyal Değişmenin Yaşam Kalitesi Algısı ve Yavaş Şehir Olma Tutumu Üzerindeki Etkisi’ isimli doktora tezinden üretilmiştir.

* Öğr. Gör. Dr., Ondokuz Mayıs Üniversitesi, Samsun Meslek Yüksekokulu, olcay.yapici@ omu.edu.tr, ORCID: 0000-0002-5197-5313

** Prof. Dr., Selçuk Üniversitesi, Turizm Fakültesi, safakunuvar@selcuk.edu.tr, ORCID: 0000-0001-9177-8704
} 


\section{GİRIŞ}

Turizm faaliyetlerinin önemi gün geçtikçe artış göstermekte ve turizm, insanların fiziksel, sosyal ve psikolojik ihtiyaçlarına gerek doğrudan gerekse dolaylı olarak etki etmektedir. Turizm faaliyetleri ile birlikte toplumsal refah düzeyi yükselmektedir (Gürbüz, 2002:50). Ancak unutulmaması gereken bir diğer etki ise turizmin toplum üzerindeki etkidir. Son zamanlarda turizm faaliyetleri çok çeşitli olayları kapsamaktadır. Turizmin etkileri kişisel davranışlara, aile içi ilişkilere, ahlak kurallarına, sanatsal çalışmalara, yeme içme alışkanlıklarına kadar birçok sosyal olguya etki etmektedir.

Turizm faaliyetleri yavaş şehir hareketi ile sıklıkla anılan bir endüstri haline gelmiştir (Acuner,2015:57). Turizmin gelişmesi ve bir ülkenin dünya çapında tanıtılması ülkenin ekonomik, sosyal ve kültürel gibi çok sayıda değişkenlerine bağlı olmaktadır (Tosun ve Bilim,2004:125). Yavaş şehir felsefesi uluslararası boyutta değerlendirildiğinde küçük şehirlerin kendilerine özgü değerlerinin korunması ve geliştirilmesi ile turistik açıdan çekiciliklerinin artırılması amaçlanmaktadır. Modern dünyada eğitim seviyesinde artışların yaşanması ile birlikte gelişmekte olan ve gelişmiş ülkelerdeki insanlar sıradan destinasyonlara gitmek yerine özgün destinasyonlara gitmeyi tercih etmektedir. Günümüzde turistik talebin özgün destinasyonlara doğru kaydığ söylenebilir. Yavaş şehir kavramı ise bu bağlamda modern turistik eğilimler arasında olma özelliğine sahiptir.

Yavaş şehir felsefesinin sahip olduğu değerler sürdürülebilirlikle aynı doğrultudadır. Sahip olunan doğal, ekonomik ve kültürel kaynaklar gerek yerel halkın gerek turistin gerekse gelecek nesillerin yaşam kalitesini etkileyen unsurları oluşturmaktadır. Özellikle doğal ve kültürel kaynakları yoğun bir şekilde kullanan turizm tehlike unsuru olabilmektedir. Son zamanlarda turistik açıdan yavaş şehirlerin turistik destinasyon olarak tercih edilmesi yaşam kalitesinin yanı sıra sosyal değişmeyi de beraberinde getirebilir.

Yavaş şehirlerin turistik bir destinasyon olmaya başlaması ile yerel halkta bir takım değişikliklerin meydana gelebileceği öngörülmektedir. Yavaş şehre gelen ziyaretçi sayısındaki artışlar ile birlikte yerel halkın turist ile etkileşimi sonucu sosyal değişmeler gözlemlenebilir. Nitekim turizmin sosyal, kültürel ve çevresel etkileri söz konusu olabilmektedir. Özellikle turizm faaliyetlerinin sonucu olarak yavaş şehirlerde meydana gelebilecek sosyal değişmelerin yerel halkın yaşam kalitesi algısında etkilendiği söylenebilir.

\section{KAVRAMSAL ÇERÇEVE}

Kavramsal çerçeve kapsamında çalışmanın alan yazınını oluşturan yavaş şehir, sosyal değişme ve yaşam kalitesi kavramları açıklanmıştır.

\subsection{Yavaş Şehir}

İtalyanca bir kelime olan "Citta" ile İngilizce bir kelime olan "Slow" kelimelerinin bir araya gelmesi ile oluşan Cittaslow kelimesi Türkçe "Yavaş Şehir" ya da "Sakin Şehir" anlamına gelmektedir (Pajo ve Uğurlu, 2015:66). Yavaş şehir hareketi nüfusu 1.500 ile 50.000 arasında yer alan kentlerin katılabildiği bir birliktir. Yöresel değerlerin korunması, geleneksel ürünlerin ve üretimin korunması yavaş şehir akımının amaçları arasında yer almaktadır (Güven, 2011:116). Cittaslow'a üyelik süreci kentin başkanının yazmış olduğu başvuru mektubu Cittaslow Türkiye Koordinatörlüğü'ne sunulmaktadır. Başvuru mektubunda kentin sahip olduğu özellikleri, başvuru sebebi ve gerekçeleri, kentin kriterlere uygunluk düzeyi ve uygun olmayan kriterler için planlanan projeler, aday kentin birlik ile iletişim kuracak olan kişisine ilişkin bilgiler yer almalıdır. Aday kentin mektubunun kabulünün ardından adaylık için ön değerlendirme yapılmaktadır.

Yavaş şehir hareketi Türkiye'de ilk olarak İzmir'in bir ilçesi olan Seferihisar'ın 2009 yılında ağa dahil olması ile başlamıştır. 2010 yılı itibariyle de çok sayıda kent Cittaslow olmak için çeşitli çalışmalara başlamıştır. Nisan 2020 itibariyle Türkiye'de Cittaslow olan kent sayısı 18'e yükselmiştir. 2011 yılında Muğla'da Akyaka, Aydın'da Yenipazar, Çanakkale'de Gökçeada, Sakarya'da ise Taraklı uluslararası ağa katılmışlardır. 2012 yılında ise Kırklareli'nde Vize, Ordu'da Perşembe ve Isparta'da Yalvaç katılmışlardır. 2013 yılında ise Şanlıurfa'da Halfeti, 2015 yılında Artvin'de Şavşat, 2016 yılında Erzurum'da Uzundere, 2017 yılında ise Sinop'ta Gerze, Isparta'da Eğirdir, 2018 yılında Bolu'da Göynük ve Mudurnu, 2019 yılında Muğla Köyceğiz ve Bitlis'te Ahlat yavaş şehir olarak ilan edilmiştir.

Sürdürülebilir turizm, hem gelecek hem de mevcut zaman için doğal kaynakların devamlılı̆̆ının olmasını sağlayan, toplumların gelenek ve göreneklerini devam ettirerek turizm deneyimi yaşamalarını sağlayan, ev sahibi bölgede elde edilen kazancın adil dağılmasını sağlayan turizm ve ilişkili sistemlerdir (Çelik, 2016:69). Turizmin olumsuz etkilerini en aza indirgemede sürdürülebilir turizm bir alternatiftir (Deniz, 2015:219). Yavaş şehir hareketinin merkezinde yer alan yerellik ve yerel halk, yerel halkın katılımı sürdürülebilir turizm gelişimi için önemlidir. Sürdürülebilir turizmin anahtar noktası yavaş yemek, yavaş şehir ve yavaş turizmdir. Belirtilen üç içerik sürdürülebilir turizm gelişimi ile bağlantılıdır. Yavaş yemek, yavaş şehir gelişimi kentlerin ve destinasyonların yayılmasında bir araçtır (Heintmann ve diğerleri, 2011:114-122). 


\subsection{Sosyal Değişme}

Sosyolojide karşılaşılan sosyal değişme kavramı, toplumlarda dünya görüşüne ilişkin ortaya çıkan farklılaşmayı kapsamaktadır (Doğan,2005:32). Farklılaşma; kültürel anlamda nüfus ve sosyal tabakalaşmayı, fiziksel olarak yerleşim tarzını kapsamaktadır (Erkal,2012:298). Sosyal değişime ilişkin alan yazında farklı tanımlamalar yapılmıştır. Özkalp'e (2011) göre sosyal değişme bir grubu etkileyen davranış ve uygulamaların grup tarafından değiştirişine yönelik tutumlardır (Özkalp, 2011:9). Doğan'a (1998) göre sosyal değişme ise bir kitlenin problem ile karşılaşması durumunda çözüm üretebilmek adına yaşam şekillerinde değişimin ortaya çıkmasıdır (Doğan, 1998:179).

Alan yazındaki tanımlamalardan hareket ile sosyal değişme, toplumda farklı nedenlerden ötürü ortaya çıkan olaylar karşısında gösterilen tutum ya da davranışların zaman içerisinde farklılık göstermesi şeklinde tanımlanabilir. Sosyal değişmeyi olumlu ya da olumsuz şeklinde değerlendirmek yetersiz kalacaktır. Toplumda meydana gelen bir olayın toplumun değerlerini olumsuz etkilemesi ile olumsuz anlamda sosyal değişme yaşanabilirken toplumsal değerlerin korunması ve nesillere aktarılmasına yardımcı olmasını sağlayan bir olay ise olumlu yönde sosyal değişmeyi sağlayabilir. Huttasin'in (2008) yapmış olduğu çalışmada turizm dolayısı ile meydana gelen sosyal değişmenin olumlu ve olumsuz şekilde olabileceği örnekleri verilmiştir. Hırsızlık oranının ve madde bağımlılığının artması, tarım ile ilgilenen kişi sayının azalması şeklinde olumsuz etkileri görülürken kadının rolünün değişmesi, alt yapı ve üst yapıdaki iyileşmeler şeklinde olumlu değişiklikler de söz konusudur.

Turizm sosyal, kültürel ve ekonomik anlamda değişim kaynağı olarak görülebilir. Turizm ile birlikte geleneksel değerler farklılaşma yaşamaktadır. Turizm faaliyetleri ile uzaktan ya da yakından ilişkili olan toplumlarda değişim olayı yadsınamaz bir gerçektir. Turizmden kaynaklanan sosyal yapı değişimi ile topluluklar sosyo-ekonomik açıdan sıkıntı yaşamadan, kültürel değerlerin korunarak, tutucu görüşlerin kısa zaman dilimi içerisinde sönmesi ile sorunsuz bir değişim süreci içerisinde yer alacaklardır (Eralp,1974).

Huttasin (2008) tarafından yapılan çalışmada sosyal değişeme kavramının altı boyutta değerlendirilmesi gerektiği vurgulanmıştır. Sosyal değişme; giyim, dil, yeme-içme alışkanlıkları, ailevi değerler, sosyal değerler ve sosyal süreçler olarak değerlendirilmiştir. Turizm giyim şeklinin değişmesini etkileyen faktörlerden biri olarak düşünülebilir. Turizm giyim konusundaki farklılıkların ortaya çıkmasını tetiklemektedir (Huttasin,2008; Telfer ve Sharpley,2008:197 ). Turizmin dil üzerindeki etkisi kabul gören bir durumdur. Turistler bir bölgeyi ziyaret ettiklerinde yerel halkın kendi dillerini konuşmalarını talep etmekte ve yerel halk turistlerin dilini öğrenerek konuşmaya başlamaktadır (Coltman,1989:253). Gaul (2003)'a göre turizm faaliyetleri ile birlikte hızlı nüfus artışı, sosyal ilişkilerde bozulma ve hatta yerel halkın yeme içme alışkanlıklarında değişmeler ve bozulmalar meydana gelmektedir. Turist ve yerel halkın bir araya gelmesi ile her iki taraf da birbirinden etkilenmektedir. Yerel halk ve turist arasındaki iletişim öncelikli olarak aile üzerinde etkili olmaktadır (Kadanalı ve Yazgan, 2012:99). Turizm faaliyetleri ile birlikte yerel halkın itibarının artmas1, geleneksel değerlerin korunmas1, dostluk ve hoşgörü gibi kavramlar yerleşmektedir (Özmen, 2007:3336). Turizm endüstrisi ile birlikte kumar, fahişelik, alkol gibi aşırılıklar artmakta, yerli halk turistler tarafından kullanılan lüks ve ithal mallara talep göstermekte, kimi zaman ırksal gerginlikler yaşanmaktadır. Turizm işinde çalışanlara köleye yönelik tutumların, ev sahibi halkın kültüründe yozlaşmanın meydana geldiği görülmektedir (Gürkan, 1996:41-42).

\subsection{Yaşam Kalitesi}

Yaşam kalitesi, çevreye ait ölçülebilen mekânsal, fiziksel ve sosyal bileşenlerin bir arada değerlendirilmesi ile birlikte bireylerin algılarının hem öznel hem de nesnel değerlendirilmesidir (Von Kamp Leidelmeijer, Marsman ve Hollander, 2003). Dünya Sağlık Örgütü yaşam kalitesini; insanların değer sistemleri içerisinde kendi durumlarını algılama biçimi şeklinde tanımlamıştır. Tanımlardan hareketle yaşam kalitesi, birey ya da toplumun huzur, refah, mutluluk duygularını ve algısını etkileyen tüm değerleri kapsamaktadır (Oprescu, 2011:176).

Yaşam kalitesi ile ilgili çalışmalarda bireyin mi yoksa toplumun mu öncelikli olması gerektiği tartışma konusu olmuştur. Yaşam kalitesi yaklaşımları bireysel ve bireyi aşan yaklaşımlar olmak üzere ikiye ayrılmışır. Bireysel yaklaşımlarda kişinin istek ve ihtiyaçlarının toplumsal düzenin önünde olduğu düşünülmektedir. Bireylerin güvenlik ihtiyacının karşılanmasında toplumsal düzen etkindir. Bireyi aşan yaklaşımlarda ise kişinin toplumsal düzene olan liykatini, toplumsal öncelikleri savunmaktadır (Gerson, 1976). Yaşam kalitesi konusunda bireysel yaşam kalitesi ve toplumsal yaşam kalitesini birlikte değerlendirmek kaçınılmaz olacaktır. Turizm gün geçtikçe festivaller, restoranlar, doğal ve kültürel çekim merkezleri gibi dış mekan faaliyetleri ile yerel halkın katılmaktan keyif alarak yaşam kalitesini yükselttiği bir endüstri olarak görülmektedir. Gelişmiş yaşam kalitesi, kişisel yaşam standardının yüksekliği, vergi gelirindeki artış, iş olanaklarındaki artış ve 
ekonomik çeşitlilik yerel halkın yaşam kalitesine yönelik algıyı olumlu yönde etkilemektedir (Andereck ve di ̌̆., 2007:485).

Sağlık, ekonomi, mutluluk gibi çok sayıda faktör yaşam kalitesi üzerinde etkilidir. Bu noktada bireysel ve toplumsal olmak üzere yaşam kalitesi iki boyutta ortaya çıkabilir. Ekonomik seviye bireysel yaşam kalitesini gösterirken ülkenin eğitim düzeyi toplumsal yaşam kalitesi ile ilişkilidir (Das, 2008:297; Erkul ve Karakılçık, 2000:87). Yaşam kalitesi, insanların dünya görüşleri, değerleri, amaçları, inançları ile birlikte şekillenen bir kavramdır. Yaşam kalitesi kavramı iç ve dış kalite unsurlarını kapsamaktadır. Bireysel dünya görüşü insanları aldatarak insanın tam olarak odaklanmasını engeller ve zihinsel olarak yapması gereken yorumu yapamaz. Bu durumda kişi yorgun, mutsuz, keyifsiz olarak içsel yaşam kalitesini düşürmektedir. İçsel yaşam kalitesinin düşmesi ile birlikte dışsal kalite de düşüş göstermektedir (Bıçakc1,2001: 7; Öztuna,2007:37).

İnsanların gündelik hayatlarında karşılaştıkları televizyon, internet, gazete, politika, ekonomi, çalışma hayatı, günlük faaliyetler yaşam kalitesini etkileyen unsurlardır. Ekonomik krizler, şehir sorunları, sağlık sorunları, kalabalık, ulaşımla ilgili sorunlar, stres ve çatışma yaşam kalitesini olumsuz olarak etkileyen faktörler arasında gösterilmektedir (Demirkıran,2012:8). Yaşam kalitesi insanların ruhsal iyi olmaları, fiziksel iyi olmaları, sosyal iyi olmalarını içeren dinamik ve çok boyutlu bir bileşendir. Yaşam kalitesi insanların biyolojik durumlarıyla doğrudan ilişkili olmakla birlikte fiziksel, bilişsel ve sosyal durumları da kapsayan çok boyutlu yapıdadır (Yıldırım ve Fadıloğlu, 2005:35). İnsanların yaşam kalitelerinin istenen düzeyde olması için birtakım unsurların bir arada olması gerekmektedir. Sağl1k ve eğitim hizmetlerinin iyi olması, temiz bir çevre, günlük yaşam faaliyetlerine katılabilme durumu, firsat eşitliği, dengeli beslenme, güvenlik ve saygınlık yaşam kalitesini artıran unsurlardır (Zorba,2014:82).

Dünya Sağlık Örgütü'nün yaşam kalitesi modeline göre fiziksel sağllğı oluşturan bileşenler, enerjiyorgunluk, ağrı-rahatsızlık ve uyku-dinlenme şeklinde tanımlanmıştır. Psikolojik iyi olma alt boyutunu oluşturan bileşenler ise bedensel imaj ve diş görünüş, olumlu düşünceler, olumsuz düşünceler, düşünmeöğrenme ve öz benlik şeklindedir. Bağımsızlık durumunda hareket edebilme rutin yaşam faaliyetleri, ilaçlara ve tedaviye bağl1lık ve çalışma kapasitesi bileşenleri yer almaktadır. Sosyal ilişkiler alt boyutunun bileşenleri ise kişisel ilişsiler, sosyal destek ve cinsel faaliyetler olarak tanımlanmıştır. Finansal kaynaklar, fiziksel güvenlik, sağlik ve sosyal hizmetlere ulaşabilme, ulaşım çevresel koşulları oluşturan bileşenlerdir. Manevi değerler alt boyutunun bileşenleri ise din, manevi değerler ve inançlar yer almaktadır (WHO, 1997:4).

\section{2. İLGİLI ÇALIŞMALAR}

Turizm gelişimi konusunda yerel halkın algısı ve tutumuna yönelik olarak 1970li yıllardan beri çok sayıda araştırmalar yapılmaktadır. Pioneers'in yapmış olduğu çalışmada turizmin olumlu ekonomik etkilerinden bahsederken Pizam ve Rotham'ın yapmış olduğu çalışmalarda ise turizmin olumsuz ekonomik etkilerinden bahsedilmektedir. 1980li yıllarda turizmin ekonomik etkilerinin yanı sıra sosyal etkileri de araştırma konusu olmaya başlamıştır (Pavlie, Portolan ve Puh,2015:260). Turizmin yoğun olmaya başladığ1 yerlerde göçün azalması ile birlikte nüfusta yoğunlaşma meydana gelmektedir. Nüfusun artması neticesinde alt yapı, elektrik, yol, su vb. ögelerde değişme meydana gelirken mesleki farklılıklar ve ayrılıklar ortaya çıkmaktadır (Akman, 2007:123; Montero, 2011).

Huttasin (2008) tarafından yapılan çalışmada sosyal değişim üzerinde turizmin ne derece etkisi olduğu araştırılmıştır. Huttasin'in çalışması Tayland'da bulunan OTOP turizm köyleri üzerine geliştirilmiş bir modeldir. 1997 yılında Taylan'da ortaya çıkan ekonomik kriz sonucunda her köye bir ürünün pazarlanması şeklinde bir turizm faaliyeti planlanmıştır. Bölgede turizmin geliştirilmesi adına yerel değerlerin korunması ve sürdürülebilirliğin sağlanması hedeflenmiştir. Bu proje ile birlikte yerel halkta bir takım değişimlerin olacağ tahmin edilmiştir. Bir bölgede turizm gelişiminin paydaşlarından biri olan yerel halkın turizm gelişimine yönelik tutumu oldukça önemlidir (Pavlian, Portolan ve Puh, 2015:259).

Turizmin sosyal, çevresel, kültürel ve ekonomik etkileri bağlamında yerel halkın tutumu üzerine çalışma yapan araştırmacılar iki konunun birbiri ile ilişkili olduğunu dile getirmişlerdir (Pavlian, Portolan ve Puh, 2015:260). Turizm ile birlikte yerel halkın kültüründe, giyiminde, yaşam tarzında ve bunun gibi pek çok farklı alanda değişim görülmektedir. Özellikle az gelişmiş ülkelerde değişim olayının daha çok görüldüğü gözlemlenmiştir (Ünlüönen ve Tayfun, 2003). Uluslararası turizm hareketinin giderek artması ile birlikte çok sayıda araştırmacı özellikle küçük ölçekli yerlerde kültürel etkileşim sonucu ortaya çıkan sosyal değişim ile ilgilenmeye başlamıştır (Lane, 2009:66). Machado (2018) tarafından Portekiz üzerine yapılan araştırmada, Portekiz'in dünyadaki iyi destinasyonlardan birisi seçildiği ancak Portekiz yerel halkının yaşam kalitesinin korunması, turist deneyimlerinin korunması ve geliştirilmesi için stratejilerin geliştirilmesi gerektiği sonucuna ulaşılmıştır. 
Bireysel yaşam kalitesi, turistlerle paylaşılan alan ve çevre, yaşam kalitesinin değerlendirilmesi yerel halkın algılarının merkezinde yer almaktadır. Turistik bölgelerdeki yerel halkın yaşam kalitesi algısı, yaşamlarını keyifli hale getiren, bireysel ve toplumsal yaşam kalitesine katkı sağlayan, tehdit unsuru olarak görülmeyen şekildedir (Vogt ve diğerleri, 2016:36). Vogt, Jordan, Grewe and Kruger (2016:41) tarafindan Alaska'da küçük turistik bir adada bireysel yaşam kalitesi üzerine yapılmış çalışmada turistik faaliyetler için yapılan çalışmaların yaşam kalitesini olumlu yönde etkilediği sonucuna ulaşılmıştır. Suess, Baloglu ve Busser (2018) tarafindan turizm gelişiminin toplumsal yaşam kalitesi üzerine etkileri araştırılmıştır. Araştırma LasVegas'ta 291 kişi ile anket yapılarak gerçekleştirilmiştir. Çalışmanın sonuçlarına göre yerel halk turizm gelişiminin toplumsal yaşam kalitesini olumlu yönde etkileyeceği konusunda hemfikirdir. Yerel halk turizm gelişimini gelecek için bir tehdit unsuru olarak algılamamaktadır. Kim, Uysal ve Sirgy (2013) tarafindan yapılan çalışmaya göre turizm yerel halkın toplumsal yaşam kalitesi üzerinde etkilidir. Çalışma bulguları aynı zamanda turizmin sosyal etkileri ile yerel halkın toplumsal yaşam kalitesi algısının olumlu yönde ilişkili olduğunu göstermektedir. Yerel halk tarafından turizmin algılanan olumlu sosyal etkisi arttıkça toplumsal yaşam kalitesi de artış gösterecektir. Lian, Hui (2016:66) tarafindan Çin'de 562 kişi üzerine turizm ve yaşam kalitesini ölçmek amacıyla ölçek geliştirmişlerdir. Çalışmada toplam turizm yaşam kalitesinin turizm gelişimine daima olumlu katkı sağlamadığı sonucuna ulaşılmıştır. Turizm gelişimi konusunda yerel halkın desteğinin alınması ancak gelişmelere yönelik daha dikkatli olunması gerekmektedir. Croes, Ridderstaat ve Niekerk (2018:221) tarafindan Malta'da yapılan araştırmanın sonuçlarına göre uzun dönemde turizm yaşam kalitesi üzerine olumsuz etki etmektedir. Karmaşık yapısı itibari ile bu etki zamanla azalabilir, hatta ortadan kalkabilir. Kısa dönem sonuçları turizmin Malta yerel halkının yaşam kalitesi üzerinde olumlu etkilerinin olduğunu ortaya koymaktadır.

Turizm sektörü dünyada hızlı gelişme gösteren sektörler arasında yer almaktadır. Bu sektör hem doğal hem de kültürel kaynaklardan beslenmektedir. Dolayısı ile doğal ve kültürel kaynakların zarar gördüğü ortamlarda turizm faaliyetlerinden söz etmek mümkün değildir. Sürdürülebilirlik kavramı bu açıdan turizm sektörü için oldukça önemlidir (Demir ve Çevirgen, 2006:99). Sürdürülebilir turizm, hem gelecek hem de mevcut zaman için doğal kaynakların devamlılığının olmasını sağlayan, toplumların gelenek ve göreneklerini devam ettirerek turizm deneyimi yaşamalarını sağlayan, ev sahibi bölgede elde edilen kazancın adil dağılmasını sağlayan turizm ve ilişkili sistemlerdir (Çelik, 2016:69). Turizmin olumsuz etkilerini en aza indirgemede sürdürülebilir turizm bir alternatiftir (Deniz, 2015:219). Yavaş şehir hareketinin merkezinde yer alan yerellik ve yerel halk, yerel halkın katılımı sürdürülebilir turizm gelişimi için önemlidir. Sürdürülebilir turizm gelişiminde yer alan uygulamalarda olası tüm paydaşların etkin katılımları zor bir durumdur. Tüm paydaşların etkin katılımı ile sürdürülebilir turizm uygulamalarında amaçlara ulaşılabilir (Park ve Kim, 2014:2). Sürdürülebilir turizm gelişiminde özellikle destinasyonların tanıtımında ve ekonomik olarak büyümede hükümet politikası oldukça önemlidir sürdürülebilir destinasyon yönetiminin temelinde yerel kültür, tarih, çevre ve sosyal sorumluluk yer almaktadır (Presenza ve diğ., 2015:44). Sürdürülebilir turizmin anahtar noktası yavaş yemek, yavaş şehir ve yavaş turizmdir. Belirtilen üç içerik sürdürülebilir turizm gelişimi ile bağlantılıdır. Yavaş yemek, yavaş şehir gelişimi kentlerin ve destinasyonların yayılmasında bir araçtır (Heintmann ve diğerleri, 2011:114-122).

Dünyada artış gösteren üretim ve tüketim faaliyetlerine bağlı olarak insanların yaşam alanlarında tahribat söz konusudur. Hızlı nüfus artışına paralel olarak atık miktarında artış yaşanmakta, işsizlik oranının artması ile beraber geçim kaynaklarının daralması ve ekonomik açıdan sıkıntılı süreç yaşanmaktadır. Sadece ekonomik anlamda daralma değil sosyo-kültürel açıdan da bir daralma söz konusudur (Demircan, 2016:13). Sürdürülebilir turizm faaliyetleri gerçekleştirebilmek için öncelikle planlama yapmak gerekmektedir. Planlama aşaması için bir ekip belirlenmelidir. Üst yönetimde yer alacak ekibin ardından yerel organizasyonun oluşturulması gerekmektedir. Yerel organizasyon içerisinde yerel paydaşların yer alması sağlanmalı, yerel toplum hazırlanmalıdır. Organizasyonun tamamlanmasının ardından kentin turizm potansiyeli belirlenmelidir. Kaynak analizini yapılması, turizm potansiyelinin saptanması, bölgelere göre sınıflandırma, envanter çalışması ve öncelikli alanların tespit edilmesi ile turizm potansiyeli tespit edilir. Yapılan çalışmalar sonucunda sürdürülebilir turizm stratejisi belirlenmelidir (Artun,2016: 130).

Sürdürülebilir turizmi gerçekleştirebilmek için yapılması gereken çalışmaların işleyiş aşaması yavaş şehir olma aşamalarıyla benzerlik göstermektedir. Yavaş şehir kapsamında gerçekleştirilen faaliyetlerin tümü sürdürülebilirlik adına yapılan çalışmalarla özdeşleşmektedir. Yavaş şehir hareketi paydaşların süreçte etkin bir şekilde yer alması ve toplumun sosyal yapısının şekillenmesinin sürdürülebilirliği ve gelişiminde alternatif bir model olarak değerlendirilebilir (Üstündağl1 ve diğerleri, 2015:128). Yavaş şehir hareketi, şehirlerin sakin kalarak doğal ve kültürel değerlerinin korunmasını hedeflerken ekonomideki turizm hareketinin yönünü de tayin etmeyi amaçlamaktadır. Doğal ve tarihi dokunun korunmasını savunan anlayış, kültürel mirasın ve değerlerin korunarak gelecek nesillere aktarılması ve sürdürülebilir turizmin hizmetine sunulması açısından 
önemlidir. Örneğin Türkiye'nin yavaş şehir başkenti olan Seferihisar sürdürülebilir turizmin ilkeleri açısından Selcen Seda Türksoy tarafından değerlendirilmiş ve yavaş şehir kapsamında gerçekleştirilen projelerin sürdürülebilir turizm ilkeleri ile uyumluluk gösterdiğini tespit etmiştir (Türksoy, 2016:273). Mayer ve Knox (2006), yavaş şehir hareketinin sürdürülebilirlik bağlamında alternatif kent gelişim modeli olduğunu ileri sürmektedir (Mayer ve Knox, 2006:324). Belirtilen yazarların Almanya'da bulunan yavaş şehirler olan Hersbruck ve Waldkirch üzerine yaptıkları çalışmada, alternatif gelişim modeli sağlama kamu, özel sektör ve gönüllülerin iş birliği ile oluşmaktadır. Yavaş şehir olma özelliği ve çoklu yollardan desteklenmesi ile kentsel gelişim süreci gerçekleşmektedir (Mayer ve Knox, 2006:331).

\section{YÖNTEM VE BULGULAR}

\subsection{Yöntem}

$\mathrm{Bu}$ çalışmanın amacı yavaş şehirlerde turizm hareketlerinden kaynaklı sosyal değişmenin yerel halkın bireysel ve toplumsal yaşam kalitesi üzerine etkilerinin incelenmesidir. Araştırma yavaş şehir olan Gerze'de yerel halk üzerinde gerçekleştirilmiştir. Bu çalışma turizm ana temasında sosyal değişme ve yaşam kalitesi arasındaki ilişkinin yavaş şehirlerde nasıl olduğu konusuna değinmesi ve daha önce alan yazında yapılmaması açısından önem arz etmektedir. Bu kapsamda araştırmada hazırlanan hipotezler aşağıda yer almaktadır.

Hipotez 1: Sosyal değişme toplumsal yaşam kalitesi algısı üzerinde anlamlı bir etkiye sahiptir.

Hipotez 2: Sosyal değişme bireysel yaşam kalitesi algısı üzerinde anlamlı bir etkiye sahiptir.

Araştırmanın uygulama alanı olarak Sinop'un Gerze ilçesi ve hedef kitlesi olarak Gerze'de yaşayan yerel halk seçilmiştir. Gerze'de yaşayan on sekiz yaşından büyük herkes araştırmanın hedef kitlesine girmektedir (N=12314). Uygulamanın sadece Gerze'de yaşayanlar ile yapılması coğrafi açıdan bir kısıt oluşturmaktadır. Ayrıca verilerin Mart-Nisan 2019 tarihleri arasında toplanması da zaman açısından kısıt oluşturmaktadır.

Sinop ilinin Gerze ilçesinde gerçekleştirilen araştırma öncesinde resmi kurumlara başvuru yapılarak Gerze'de yaşayan toplam nüfus bilgisi 24946 şeklinde temin edilmiştir. Türkiye İstatistik Kurumu'nun sağladığı verilere göre Gerze'de ikamet eden on sekiz yaş üstü kişi sayısı 12314 olarak belirlenmiştir. Araştırma için Gerze seçilme nedeni bu bölgenin yavaş şehir olması sebebiyle yerel halkın sosyal değişmeye yönelik düşünceleri ve yaşam kalitesine ilişkin algısını etkileyebileceği düşünülmektedir. Araştırmada veri toplama aracı olarak nicel araştırma yöntemlerinden anket tekniği kullanılmıştır. Çalışmada rastgele örneklem yöntemi kullanılmıştır. Veri toplama süreci yaklaşık iki ay sürmüştür. Pilot uygulama Mart 2019'da yapılmıştır. Anket toplama sürecini araştırmacı şahsen yürütmüştür. Dağıtılan toplam 600 anketten 429 tanesi geri dönmüş, geri dönen anketlerin ise 19 tanesinin düzgün doldurulmadığ tespit edilmiştir. Buna göre toplam 410 kullanılabilir anket elde edilmiştir.

Araştırma için geliştirilen anket formu iki bölümden oluşmaktadır. Birinci bölümde katılımcıların demografik özelliklerine ilişkin on soru yer almaktadır. İkinci bölümde ise sosyal değişmeye ilişkin 33 önerme, yaşam kalitesine ilişkin 15 önerme yer almaktadır. Sosyal değişme ölçeği; otuz üç önermeden oluşan sosyal değişme ölçeği katılımcıların toplumda meydana gelen sosyal değişme algılarını ölçmeyi hedeflemektedir. Sosyal değişme ölçeği Huttasin'in (2008) turizmde sosyal değişimi incelediği çalışmasında kullandiğı ölçektir. Sosyal değişme ölçeği; giyim, dil, yeme-içme alışkanlıkları, ailevi değerler, sosyal değerler ve sosyal süreçler olmak üzere altı alt boyuttan oluşmaktadır. Yaşam kalitesi ölçeği olarak Özyurt (2018) tarafından Türkçeye uyarlanmış ölçek kullanılmıştır. Yaşam kalitesine ilişkin önermelerin cevaplarında hiç memnun değilim ile çok memnunum şeklinde beşli likert ölçeği kullanılmıştır.

\subsection{Bulgular}

İstatistiksel analizler SPSS 22 paket programı yardımıyla gerçekleştirilmiştir. Çalışmada kullanılan ölçeklere ilişkin tanımlayıcı istatistikler ortalama ve standart sapma şeklinde sunulmuştur. Araştırma hipotezleri basit doğrusal regresyon analizleri yardımıyla test edilmiştir. Ölçeklerin güvenilirliği Cronbach alpha katsayısı ile kontrol edilmiştir. İstatistiksel anlamlılık için $\mathrm{p}<0.05$ değeri kullanılmıştır. Tablo 1'de çalışmaya katılan bireylerin demografik özelliklerine ilişkin bilgiler sayı (n) ve yüzde (\%) olarak sunulmuştur.

Tablo 1: Katılımcıların Demografik Özellikleri

\begin{tabular}{lcc}
\hline Demografik Özellikler & Sayı (n) & Yüzde (\%) \\
\hline Cinsiyet & 188 & 44.9 \\
Kadın & 231 & 55.1 \\
Erkek & 231 \\
\hline
\end{tabular}




\begin{tabular}{|c|c|c|}
\hline \multicolumn{3}{|l|}{ Yaş } \\
\hline 18-25 Yaş & 103 & 24,6 \\
\hline $26-33$ Yass & 75 & 17,9 \\
\hline 34-41 Yaş & 92 & 22 \\
\hline 42-49 Yaş & 63 & 15 \\
\hline 50-57 Yaş & 43 & 10,3 \\
\hline 58-65 Yaş & 31 & 7,4 \\
\hline 66 ve üstü yaş & 12 & 2,9 \\
\hline \multicolumn{3}{|l|}{ Eğitim } \\
\hline İlkokul & 35 & 8,4 \\
\hline Ortaokul & 32 & 7,6 \\
\hline Lise & 107 & 25,5 \\
\hline Ön lisans & 105 & 25,1 \\
\hline Lisans & 115 & 27,4 \\
\hline Lisan üstü & 25 & 6 \\
\hline \multicolumn{3}{|l|}{ Medeni Hal } \\
\hline Bekar & 176 & 42 \\
\hline Evli & 243 & 58 \\
\hline \multicolumn{3}{|l|}{ Çocuk Sayısı } \\
\hline 1 & 79 & 18,9 \\
\hline 2 & 111 & 26,5 \\
\hline 3 & 42 & 10 \\
\hline 4 & 10 & 2,4 \\
\hline 5 & 1 & 0,2 \\
\hline 6 & 1 & 0,2 \\
\hline 8 & 1 & 0,2 \\
\hline \multicolumn{3}{|l|}{ Meslek } \\
\hline Esnaf & 35 & 8,4 \\
\hline İşçi & 91 & 21,7 \\
\hline Ev Hanımı & 37 & 8,8 \\
\hline Öğrenci & 79 & 18,9 \\
\hline Mühendis & 6 & 1,4 \\
\hline Öğretmen ve Akademisyen & 83 & 19,8 \\
\hline Sağlık Çalışanı & 2 & 0,5 \\
\hline Diğer & 33 & 7,9 \\
\hline Emekli & 53 & 12,6 \\
\hline \multicolumn{3}{|l|}{ Aylık Gelir } \\
\hline 2020 TL ve altı & 181 & 43,2 \\
\hline 2021-3021 TL & 101 & 24,1 \\
\hline $3022-4022 \mathrm{TL}$ & 68 & 16,2 \\
\hline 4023 TL ve üzeri & 69 & 16,5 \\
\hline \multicolumn{3}{|l|}{ Gerze'de İkamet Y1lı } \\
\hline $1-5$ y1l & 124 & 29,6 \\
\hline $6-10$ y1l & 63 & 15 \\
\hline $11-15$ yll & 36 & 8,6 \\
\hline $16-20$ y1l & 30 & 7,2 \\
\hline 21 yıl ve üzeri & 166 & 39,6 \\
\hline \multicolumn{3}{|c|}{ Dışarda yemek yeme sıklığınız nedir? } \\
\hline Dişarda yemek yemem & 104 & 24,8 \\
\hline Haftada 1 & 159 & 37,9 \\
\hline Haftada 2-4 kez & 119 & 28,4 \\
\hline Haftada 5-7 kez & 23 & 5,5 \\
\hline Haftada 8 ve üzeri kez & 14 & 3,3 \\
\hline \multicolumn{3}{|c|}{ Yavaş şehir hakkında bilginiz var mı? } \\
\hline Evet & 354 & 84,5 \\
\hline Hayır & 65 & 15,5 \\
\hline
\end{tabular}

Tablo 1'e göre ankete katılanların \%44,9'u kadın, \%55,1'i erkekti. Bireylerin \%24.6's1 18-25 yaş aralığında, \%17.9'u 26-33 yaş aralığında, \%22'si 34-41 yaş aralığında, \%15'i 42-49 yaş aralığında, \%10.3'ü 50-57 yaş aralığında, \%7.4'ü 58-65 yaş aralığında ve \%2.9'u ise 66 ve üstü yaşındadır. Katılımcıların \% 8.4 'ü ilkokul, \%7.6'sı ortaokul, \%25.5'i lise, \%25.1'i ön lisans, \%27.4'ü lisans ve \%6's1 lisansüstü mezunudur. Ankete katılanların \%42'si bekar, \%58'i evlidir. 1 çocuk sahibi olanların oranı \%18.9, 2 çocuk sahibi olanların 
oran $1 \% 26.5,3$ çocuk sahibi olanların oranı \% 10,4 çocuk sahibi olanların oranı $\% 2.4$ ve 5,6 ve 8 çocuk sahibi olanların oranı ise her biri için \%0.2'dir. Katılımcıların \%8.4'ü esnaf, \%21.7'si işçi, \%8.8'i ev hanımı, \%18.9'u öğrenci, \%1.4'ü mühendis, \%19.8'i öğretmen ve akademisyen, \%0.5'i sağlık çalışanı, \%7.9'u diğer ve \%12.6's1 emeklidir. \%43.2'sinin aylık geliri 2020 tl ve altında, \%24.1'inin aylik geliri 2021-3021 TL aralığında, \%16.2'sinin aylık geliri 3022-4022 TL aralığında ve \%16.5'inin aylık geliri ise 4023 TL ve üzerindedir. Gerze'de 1-5 yıl aralığında ikamet edenlerin oranı \%29.6, 6-10 yıl aralığında ikamet edenlerin oranı \% 15, 11-15 yıl aralığında ikamet edenlerin oranı \%8.6, 16-20 yıl aralığında ikamet edenlerin oran1 \% 7.2 ve 21 yıl ve üzerinde ikamet edenlerin oranı ise \%39.6'dır. Katılımcıların \%24.8'i dışarda yemek yemediğini, \%37.9'u haftada $1 \mathrm{kez}, \% 28.4$ 'i $2-4 \mathrm{kez}, \% 5.5$ 'i $5-7 \mathrm{kez}, \% 3.3$ 'ü ise haftada 8 ve daha fazla kez dişarda yemek yediğini belirtmişlerdir. Çalışmaya katılanların \%84.5'i yavaş şehir hakkında bilgi sahibi iken, \%15.5'i bilgi sahibi değildir.

Tablo 2: Ölçek ve Faktörlerin Güvenilirlik Değerleri

\begin{tabular}{lccc}
\hline Ölçekler ve Faktörler & Ort & SS & Cronbach Alpha \\
\hline Sosyal Değişme Ölçeği & 3,33 & 1,13 & 0,872 \\
Giyim Faktörü & 2,77 & 1,15 & 0,682 \\
Dil Faktörü & 3,10 & 1,14 & 0,573 \\
Yeme-İ̧̇me Faktörü & 3,48 & 1,14 & 0,606 \\
Ailevi Değerler Faktörler & 3,38 & 1,11 & 0,655 \\
Sosyal Değerler Faktörü & 3,69 & 1,06 & 0,772 \\
Sosyal Süreçler Faktörü & 3,61 & 1,09 & 0,762 \\
Yaşam Kalitesi Ölçeği & 3,39 & 1,20 & 0,887 \\
Bireysel Yaşam Kalitesi Faktörü & 3,50 & 1,13 & 0,850 \\
Toplumsal Yaşam Kalitesi Faktörü & 3,23 & 1,29 & 0,839
\end{tabular}

Ort: Ortalama, SS: Standart sapma

Tablo 2'ye göre, sosyal değişme ölçeği geneli ortalaması 3.33 ve güvenilirlik katsayısı 0.872 , giyim faktörü ortalamas1 2.77, güvenilirlik katsayıs1 0.682, dil faktörü ortalamas1 3.10, güvenilirlik katsayıs1 0.573, yemeiçme faktörü ortalamas 13.48, güvenilirlik katsayısı 0.606 , ailevi değerler faktörü ortalaması 3.38 , güvenilirlik katsayıs1 0.655, sosyal değerler faktörü ortalamas1 3.69, güvenilirlik katsayıs1 0.772 ve sosyal süreçler ortalamas1 3.61, güvenilirlik katsayısı ise 0.762 olarak hesaplanmıştır. Yaşam kalitesi ölçeği geneli ortalaması 3.39, güvenilirlik katsayısı 0.887 , bireysel yaşam kalitesi faktörü ortalaması 3.50 ve güvenilirlik katsayısı 0.850 , toplumsal yaşam kalitesi faktörü ortalaması 3.23 ve güvenilirlik katsayısı 0.839 olarak tespit edilmiştir. Araştırmada kullanılan ölçekler ve faktörler arasındaki ilişkiler Tablo 3’de verilmiştir.

Tablo 3: Çalışmada Kullanılan Ölçekler ve Faktörler Arasındaki İlişkiler

\begin{tabular}{|c|c|c|c|c|c|c|c|c|c|c|}
\hline & & 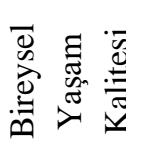 & 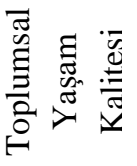 & : & $\overline{\bar{\rho}}$ & 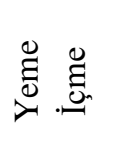 & 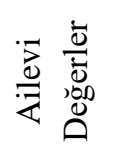 & 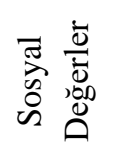 & 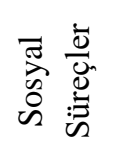 & 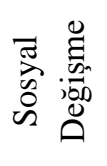 \\
\hline Yaşam & $r$ & 0.905 & 0.863 & 0.213 & 0.302 & 0.365 & 0.449 & 0.523 & 0.500 & 0.562 \\
\hline Kalitesi & $p$ & $<0.001$ & $<0.001$ & $<0.001$ & $<0.001$ & $<0.001$ & $<0.001$ & $<0.001$ & $<0.001$ & $<0.001$ \\
\hline Bireysel & $r$ & - & 0.567 & 0.190 & 0.261 & 0.346 & 0.422 & 0.459 & 0.426 & 0.504 \\
\hline $\begin{array}{l}\text { Yaşam } \\
\text { Kalitesi }\end{array}$ & $p$ & - & $<0.001$ & $<0.001$ & $<0.001$ & $<0.001$ & $<0.001$ & $<0.001$ & $<0.001$ & $<0.001$ \\
\hline Toplumsal & $r$ & & - & 0.186 & 0.276 & 0.296 & 0.364 & 0.468 & 0.464 & 0.491 \\
\hline $\begin{array}{l}\text { Yaşam } \\
\text { Kalitesi }\end{array}$ & $p$ & & - & $<0.001$ & $<0.001$ & $<0.001$ & $<0.001$ & $<0.001$ & $<0.001$ & $<0.001$ \\
\hline \multirow{2}{*}{ Giyim } & $r$ & & & - & 0.353 & 0.254 & 0.216 & 0.150 & 0.182 & 0.530 \\
\hline & $p$ & & & - & $<0.001$ & $<0.001$ & $<0.001$ & 0.002 & $<0.001$ & $<0.001$ \\
\hline \multirow{2}{*}{ Dil } & $r$ & & & & - & 0.374 & 0.419 & 0.318 & 0.318 & 0.649 \\
\hline & $p$ & & & & - & $<0.001$ & $<0.001$ & $<0.001$ & $<0.001$ & $<0.001$ \\
\hline Yeme & $r$ & & & & & - & 0.444 & 0.488 & 0.472 & 0.727 \\
\hline İçme & $p$ & & & & & - & $<0.001$ & $<0.001$ & $<0.001$ & $<0.001$ \\
\hline
\end{tabular}




$\begin{array}{llrrrr}\text { Ailevi } & r & - & 0.525 & 0.497 & 0.742 \\ \text { Değerler } & p & - & <0.001 & <0.001 & <0.001 \\ \text { Sosyal } & r & & - & 0.721 & 0.767 \\ \text { Değerler } & p & r & - & <0.001 & <0.001 \\ \text { Sosyal } & r & p & - & 0.763 \\ \text { Süreçler } & p & r & - & <0.001 \\ \text { Sosyal } & r & & - \\ \text { Değişme } & p & & -\end{array}$

Tablo 3'a göre faktörler arasında pozitif yönlü ilişkiler söz konusudur. Yaşam kalitesi ile sosyal değişme arasında $(\mathrm{r}=0.562, \mathrm{p}<0.001)$ anlamlı ve pozitif ilişki söz konusudur. Yaşam kalitesi ile sosyal değişmenin faktörlerinden giyim ile arasında $(r=0.213, p<0.001)$ en zayıf ilişki görülmüştür. Bireysel yaşam kalitesi ile sosyal değişme arasında $(\mathrm{r}=0.504, \mathrm{p}<0.001)$ da pozitif yönlü ilişki söz konusudur. Bireysel yaşam kalitesinin sosyal değişmenin faktörlerinden sosyal değerler ile $(\mathrm{r}=0.459, \mathrm{p}<0.001)$ anlamlı, pozitif yönlü en yüksek ilişkili olduğu görülmüştür. Bireysel yaşam kalitesinin sosyal değişmenin faktörlerinden giyim ile ( $\mathrm{r}=0.190$, p $<0.001)$ anlaml1, pozitif yönlü en düşük düzeyde ilişkili olduğu görülmüştür. Toplumsal yaşam kalitesinin sosyal değişmenin faktörlerinden giyim ile $(\mathrm{r}=0.186, \mathrm{p}<0.001)$ anlamlı, pozitif yönlü en düşük düzeyde ilişkili olduğu görülmüş̧ür. Toplumsal yaşam kalitesinin sosyal değişmenin faktörlerinden sosyal değerler ile $(\mathrm{r}=0.463, \mathrm{p}<0.001)$ anlaml, pozitif yönlü en yüksek ilişkili olduğu görülmüştür. Sosyal değişme ölçeği ve faktörlerinin toplumsal yaşam kalitesi algısı üzerine etkileri Tablo 4'de basit doğrusal regresyon analizi ile incelenmiştir.

Tablo 4: Sosyal Değişme Ölçeği ve Faktörlerinin Toplumsal Yaşam Kalitesi Üzerine Etkileri

\begin{tabular}{llllllll}
\hline Bağımlı Değişken & Bağımsız Değişken & $B$ & $S H$ & $\beta$ & $t$ & $p$ & $R^{2}$ \\
\hline TYK & SD & 0,946 & 0,082 & 0,491 & 11,512 & $<0,001$ & 0,241 \\
& Giyim & 0,250 & 0,065 & 0,186 & 3,868 & $<0,001$ & 0,035 \\
& Dil & 0,383 & 0,065 & 0,276 & 5,867 & $<0,001$ & 0,076 \\
& Yeme-İçme A. & 0,429 & 0,068 & 0,296 & 6,330 & $<0,001$ & 0,088 \\
& Ailevi Değerler & 0,521 & 0,065 & 0,364 & 7,969 & $<0,001$ & 0,132 \\
& Sosyal Değerler & 0,562 & 0,052 & 0,468 & 10,801 & $<0,001$ & 0,219 \\
& Sosyal Süreçler & 0,569 & 0,053 & 0,464 & 10,686 & $<0,001$ & 0,215 \\
\hline
\end{tabular}

TYK: Toplumsal Yaşam Kalitesi, Sd: Sosyal Değişme, B: Standartlaştırılmamış regresyon katsayısı, SH: Standart hata, $\beta$ : Standartlaştırılmış regresyon katsayısı, $\mathrm{R}^{2}$ : Açıklayıcılık katsayısı, İstatistiksel anlamlılık için $\mathrm{p}<0.05$ değeri kullanıldı

Tablo 4'e göre, sosyal değişmenin $(\beta=0.491, t=11.512, p<0.001)$, giyim faktörünün $(\beta=0.186, t=3.868$, $\mathrm{p}<0.001)$, dil faktörünün $(\beta=0.276, \mathrm{t}=5.867, \mathrm{p}<0.001)$, yeme-içme faktörünün $(\beta=0.296, \mathrm{t}=6.330, \mathrm{p}<0.001)$, ailevi değerler faktörünün $(\beta=0.364, \mathrm{t}=7.969, \mathrm{p}<0.001)$, sosyal değerler faktörünün $(\beta=0.468, \mathrm{t}=10.801$, $\mathrm{p}<0.001)$ ve sosyal süreçler $(\beta=0.464, \mathrm{t}=10.686, \mathrm{p}<0.001)$ faktörünün toplumsal yaşam kalitesi algısı üzerine etkileri pozitif ve istatistiksel olarak anlamlı bulunmuştur.

Yapılan analizlerden elde edilen sonuca göre: Hipotez 1: "Sosyal değişme toplumsal yaşam kalitesi algıs1 üzerinde anlamlı bir etkiye sahiptir" hipotezi kabul edilmiştir. Aynı zamanda sosyal değişmenin altı boyutu söz konusudur. Giyim, dil, yeme-içme alışkanlıkları, ailevi değerler, sosyal değerler ve sosyal süreçler boyutları da toplumsal yaşam kalitesi üzerinde anlamlı bir etkiye sahiptir. Sosyal değişmenin ve faktörlerinin bireysel yaşam kalitesi üzerindeki etkisini ölçmek amacıyla basit doğrusal regresyon analizi yapılmıştır. Analiz sonuçları Tablo 5'de verilmiştir.

Tablo 5: Sosyal Değişme Ölçeği ve Faktörlerinin Bireysel Yaşam Kalitesi Üzerine Etkileri

\begin{tabular}{|c|c|c|c|c|c|c|c|}
\hline $\begin{array}{l}\text { Bağımlı } \\
\text { Değişken }\end{array}$ & $\begin{array}{l}\text { Bağımsız } \\
\text { Değişken }\end{array}$ & $B$ & SH & $\beta$ & $t$ & $p$ & $R^{2}$ \\
\hline \multirow[t]{6}{*}{ BYK } & SD & 0,770 & 0,065 & 0,504 & 11,918 & $<0,001$ & 0,254 \\
\hline & Giyim & 0,202 & 0,051 & 0,190 & 3,954 & $<0,001$ & 0,036 \\
\hline & Dil & 0,287 & 0,052 & 0,261 & 5,514 & $<0,001$ & 0,068 \\
\hline & $\begin{array}{l}\text { Yeme- } \\
\text { İçme }\end{array}$ & 0,397 & 0,053 & 0,346 & 7,522 & $<0,001$ & 0,119 \\
\hline & $\begin{array}{l}\text { Ailevi } \\
\text { Değerler }\end{array}$ & 0,479 & 0,050 & 0,422 & 9,496 & $<0,001$ & 0,178 \\
\hline & $\begin{array}{l}\text { Sosyal } \\
\text { Değerler }\end{array}$ & 0,438 & 0,041 & 0,459 & 10,562 & $<0,001$ & 0,211 \\
\hline
\end{tabular}


Sosyal

Süreçler

0,414

0,043

0,426

9,605

$<0,001$

0,181

BYK: Bireysel Yaşam Kalitesi, Sd: Sosyal Değişme, B: Standartlaştırılmamış regresyon katsayısı, SH: Standart hata, $\beta$ : Standartlaştırılmış regresyon katsayısı, $\mathrm{R}^{2}$ : Açıklayıcılık katsayısı, İstatistiksel anlamlılık için $\mathrm{p}<0.05$ değeri kullanıldı.

Tablo 5'e göre, sosyal değişmenin $(\beta=0.504, \mathrm{t}=11.918, \mathrm{p}<0.001)$, giyim faktörünün $(\beta=0.190, \mathrm{t}=3.954$, $\mathrm{p}<0.001)$, dil faktörünün $(\beta=0.261, \mathrm{t}=5.514, \mathrm{p}<0.001)$, yeme-içme faktörünün $(\beta=0.346, \mathrm{t}=7.522, \mathrm{p}<0.001)$, ailevi değerler faktörünün $(\beta=0.422, \mathrm{t}=9.496, \mathrm{p}<0.001)$, sosyal değerler faktörünün $(\beta=0.459, \mathrm{t}=10.562$, $\mathrm{p}<0.001)$ ve sosyal süreçler $(\beta=0.426, \mathrm{t}=9.605, \mathrm{p}<0.001)$ faktörünün bireysel yaşam kalitesi algıs1 üzerine etkileri pozitif ve istatistiksel olarak anlamlı bulunmuştur.

Yapılan basit doğrusal regresyon analizine göre: Hipotez 2: "Sosyal değişme bireysel yaşam kalitesi algısı üzerinde anlamlı bir etkiye sahiptir" hipotezi kabul edilir. Giyim, dil, yeme-içme alışkanlıkları, ailevi değerler, sosyal değerler ve sosyal süreçler boyutları da toplumsal yaşam kalitesi üzerinde anlamlı bir etkiye sahiptir.

\section{SONUÇ VE ÖNERILER}

Yavaş şehirlerin sayısı her geçen gün artış göstermektedir. Yavaş şehir olgusunun daha çok önem kazanmaya başlaması ile birlikte turizm hareketi de popüler olmaya başlamıştır. Özellikle kendine has değerleri olan küçük ve şirin yerlerin gezilip görülmesi insanlar tarafından rağbet görmektedir. Yavaş hareketi hıza tepki olarak hayatın mutlu anlarını tecrübe ederek, değerini bilerek yaşamayı, acele etmeden yaşam kalitesini yükseltmeyi amaçlayan hareketleri kapsamaktadır (Sezgin ve Ünüvar, 2011:107). Turistlerin yavaş şehirleri gezip görmek ve yavaş şehirler hakkında bilgi sahibi olma yönündeki çabaları yavaş şehirlerde bir takım olumlu ve olumsuz durumları da beraberinde getirmektedir. Turizm olayının etkisi ile beraber yavaş şehirlerde sosyal bir değişmenin olup olmadığı Sinop'un Gerze ilçesinde araştırılmıştır. Turizm olayı sosyal değişmenin yanı sıra yaşam kalitesi üzerinde de etkili olmaktadır. Sosyal değişme, yaşam kalitesi başlıklarının Gerze'de nasıl bir etki içerisinde olduğu bu çalışmanın araştırma konusunu oluşturmaktadır. Araştırma kapsamında yapılan analizler sonucuna göre:

Sosyal değişme ölçeği ve faktörlerinin toplumsal yaşam kalitesi algısı üzerine etkileri pozitif ve istatistiksel olarak anlamlıdır. Gerze'de gerek giyim gerek dil gerek ailevi değerler gerek yeme içme alışkanlıkları gerek sosyal süreçler gerek sosyal değerler ile birlikte sosyal bir değişme olması durumunda toplumsal yaşam kalitesi üzerinde olumlu bir katkı sağlayacağı anlamına gelmektedir.

Sosyal değişme ölçeği ve faktörlerinin bireysel yaşam kalitesi algısı üzerine etkileri pozitif ve istatistiksel olarak anlamlı idi. Sosyal değişmenin alt faktörlerinden herhangi birine ilişin durumlarda değişiklik meydana gelmesi durumunda bireysel yaşam kalitesinde de olumlu bir durum ortaya çıkacaktır.

Gerze'de sosyal değişmenin olumlu yönde gerçekleşmesi ve buna paralel olarak gerek bireysel gerek toplumsal yaşam kalitesinin artış göstermesini sağlamak için uygulamaya yönelik önerilerden bazıları şunlar olabilir: Yavaş şehir olgusunun anlam ve önemi konusunda bilgilendirme çalışmaları daha önce yıllarda yapılmış ancak yerel halka dönük eğitim çalışmalarının sayısının artırılması gerekmektedir. Yerel yönetimler ile birlikte sivil toplum kuruluşları ve esnaf yavaş şehir felsefesinin işleyişine katkıda bulunmalıdır. Yerel halk çoğunluklu olarak yöresel ürünleri tercih etmektedir. Festivaller, toplantılar gibi organizasyonlarda özellikle turistik faaliyetlerde yöresel yemeklerin tanıtımı yapılmalıdır. Yörede yaşayan halka el sanatlarına yönelik kursların verilmesi durumu söz konusudur. Bu kurslarda süreklilik sağlanmalı ve geliştirilmesi durumunda iş imkanları konusunda yaşanan sıkıntılar aza indirilmelidir. Turistik konaklama imkanı açısından butik otellerin kurulması teşvik ve tercih edilmelidir. Kente dünyadaki diğer yavaş kentlerle sık sık bir araya gelme firsatı verilmeli ve tanıtımına katkı sağlanmalıdır.

Gerze'de çok belirgin şekilde sosyal değişmenin varlığı söz konusu değildir. Kentin küçük olması ve nüfusunun çoğunluklu olarak yaşlı olması bunun nedenleri arasında gösterilebilir. Gerze'nin yavaş şehir olması ile ilgili yapılacak tüm tanıtma faaliyetleri ile birlikte ilerleyen dönemde turizm açısından önemli bir konuma geleceği tahmin edilmektedir. Turizm olaylarının yoğun olarak görüldüğü bölgelerde sosyal değişmenin de gerçekleşmesi kaçınılmazdır. Bilinçli şekilde yapılacak turizm faaliyetleri ile sosyal değişmenin olumlu yönde gerçekleşmesi yerel halkın bireysel ve toplumsal yaşam kalitesini de olumlu yönde etkileyecektir. 


\section{KAYNAKÇA}

Acuner, E. (2015). Cittaslow (Yavaş Şehir) Olma Yolunda İlk Adım (1. Basım). Trabzon: Celepler Yayıncılık.

Akman, D. (2007). Turizmin gelişmesinin yarattığı doğal ve kültürel değişimler: Kaş örneği, Yüksek Lisans Tezi, Ankara Üniversitesi Sosyal Bilimler Enstitüsü, Ankara.

Andereck, K. L., Valentine, K. M., Vogt, C. A. and Knopf, R. C.(2007). A cross-cultural analysis of tourism and quality of life perceptions. Journal of Sustainable Tourism, 15\5, 483-502.

Artun, C. (2016). Sürdürülebilir turizmin başarı koşulları ve etkin bir turizm politikasının belirlenmesine etki eden etmenler. (ed. Hüseyin Çeken). Sürdürülebilir Turizm. Ankara: Detay yayın, 117-140

Bıçakçı, U. (2001). Paradigma ve Yaşam Kalitesi. (1. Basım). İstanbul:Sistem Yayıncılık.

Coltman, Michael M. (1989). Introduction to Travel and Tourism: An International Approach. Van Nostrand Reinhold, New York.

Croes, R., Ridderstaat, J., and Niekerk, M. (2018). Connecting quality of life, tourism specialization, and economic growth in small island destinations: the case of malta. Tourism Management, 65, 212-223.

Çelik, N. (2016). Sürdürülebilir turizm kavramı ve gelişimi. (Ed. Hüseyin Çeken). Sürdürülebilir Turizm. Ankara: Detay yayın, 67-85.

Das, D. (2008). Urban quality of life: a case study of guwahati. Social Indicators Research, 88\2, 297-310.

Demir, A., ve Çevirgen, A. (2006). Turizm ve Çevre Yönetimi Sürdürülebilir Gelişme Yaklaşımı, Ankara: Nobel Yayın.

Demirkıran, S. (2012). Yaşam kalitesi ve sağlık çalışanları. Yüksek Lisans Tezi, İstanbul: Beykent Üniversitesi Sosyal Bilimler Enstitüsü.

Deniz, M.(2015). Analysis of sustainable tourism and cittaslow potential of ulubey (uşak). (Ed. Mihaela Dinu, Necdet Hacıoğlu, Cevdet Avcıkurt, Recep Efe, Abdullah Soykan) Tourism, Environment and Sustainability. Sofia: St. Kliment Ohrıdskı University Press. 219-238.

Doğan, İ. (1998). Sosyoloji. İstanbul: Sistem Yayıncılık

Doğan, S. M. (2005). Sosyalleşme, sosyal değişme ve siyasal sosyalleşme. İstanbul Journal of Sociological Studies, 31 40.

Eralp, Z. (1974). Turizmin toplumsal değişimi sosyo-ekonomik etkisi. Ankara: Ankara Üniversitesi Yayınları.

Erkal, E. M. (2012). Sosyal değişme ve sosyal gelişmeye çağdaş bir yaklaşım. Sosyal Siyaset Konferansları Dergisi, 31 , 297-327.

Erkul, H. ve Karakılçık, Y. (2000). Belediye zabıtasının örgütsel yapısı, sorunları ve kentsel yaşam kalitesine etkilerinin irdelenmesi. Çağdaş Yerel Yönetimler Dergisi, 9\4, 86-105.

Gaul, D. (2003). Environmental impacts of ecotourism a review of literature. Web Sitesi: www.fao.org/forestry/foris/pdf/foph/ecotour.pdf, (Erişim Tarihi: 15.02.2019).

Gerson, E. M. (1976). On quality of life. American Sociological Rewiev, 41, 793-806.

Gürbüz, A. (2002). Turizmin sosyal çevreye etkisi üzerine bir araştırma. Teknoloji, 1-2, 49-59.

Gürkan, M. 1. (1996). Turizm hareketlerinin bir yerleşim biriminde (Belek/Antalya) sosyal yapıdaki değişimlere etkileri. Turizm Bakanlığı Yatırımlar Genel Müdürlüğü Araştırma ve Değerlendirme Dairesi Başkanlığı.

Güven, E. (2011). Yavaş güzeldir: yavaş yemekten yavaş medyaya hızlı tüketime dair bir çözüm önerisi. Selçuk İletişim Dergisi, 7\1, 113-121.

Heintmann, S., Robinson, P., and Povey, G. (2011). Slow food, slow cities and slow tourism. (Ed:Peter Robinson, Sine Heintmannand Peter Dieke), Research themes for tourism. London: MPG Books Group. 114-127

Huttasin, N. (2008). Perceived social impacts of tourism by residents in the OTOP tourism village, thailand. Asia Pacific Journal of Tourism Research, 13\2, 175-191.

Kadanalı, E. ve Yazgan, Ş. (2012). Kırsal turizmin ekonomik-sosyal ve çevresel etkileri. KMÜ Sosyal ve Ekonomik Araştırmalar Dergisi.14123, 97-100.

Kim, K., Uysal, M., and Sirgy M. J. (2013). How does tourism in a community impact the quality of life of community residents?. Tourism Management,36, 527-540.

Lane, P. J. (2009). Tourism and social change among the dogon. African Arts, 21, 66-92.

Lian, Z. and Hui, T. (2016). Residents'quality of lifee and attitudes toward tourism development in china. Tourism Management, 57, 56-67.

Machado, P. (2018). Challenges to portuguese tourism - restelo old man or cristiano ronaldo?, Worldwide Hospitality and Tourism Themes, 10\6, 698-704.

Mayer, H., and Knox, P. (2006). Slow cities: sustainable places in a fast world. Journal of Urban Affairs, 2814, $321-334$.

Montero, D. (2012). Some elements of a cultural theory of social change. International Journal of Social Sciences and Humanity, 2\1, 52-58.

Oprescu, G. (2011). An epistemological perspective on the quality of life concept. Theoretical and Applied Economics, 2\2, 171-180.

Özkalp, E. (2011). Sosyolojiye Giriş. Bursa: Ekin Yayıncılık

Özmen, M. (2007). Turizmin sosyo-kültürel etkileri: akçakoca örneği. Yüksek Lisans Tezi. Bolu, Türkiye: Abant İzzet Baysal Üniversitesi Sosyal Bilimler Enstitüsü.

Öztuna, B. (2007). ISO 9001:2000 Kalite yönetim sisteminin iş yaşamı kalitesine katkısı: bir araştırma. Yüksek Lisans Tezi, İzmir: Dokuz Eylül Üniversitesi Sosyal Bilimler Enstitisü. 
Özyurt, M. P. (2018). Turizm gelişiminin yerel halkın bireysel ve toplumsal yaşam kalitesi üzerine etkilerinin incelenmesi. Doktora Tezi. Antalya, Turkey: Akdeniz Üniversitesi Sosyal Bilimler Enstitüsü.

Pajo, A. Ve Uğurlu 2016). Cittaslow kentleri için slow food çalışmalarının önemi. Ejovoc (Electronic Journal of Vocational Colleges),5(6),65-73. Retrieved from https://dergipark.org.tr/tr/pub/ejovoc/issue/45166/565470

Park, E., and Kim, S. (2014). Enhancing local community's involvement and empowerment through practising cittaslow: experiences from goolwa, south Australia. SHS Web of Conference 12.

Pavlian, I., Portolan, A., and Puh, B. (2015). The social impacts of tourism on local community's quality of life. Tourism in Southern and Eastern Europe,3, 259-272.

Pizam, A. (1978). Tourism's impacts: the social costs to the destination community as perceived by its residents. Journal of Travel Research, 1614, 8-12.

Presenza, A., Abbate, T., and Perano, M. (2015). The cittaslow certification and its effects on sustainable tourism governance. Enlightening Tourism, 5\1, 40-64.

Sezgin, M. ve Ünüvar, Ş. (2011). Sürdürülebilirlik ve şehir pazarlaması ekseninde yavaş şehir. Konya: Çizgi Kitabevi.

Suess, C., Baloglu, S. and Busser, J. A. (2018). Perceived impacts of medical tourism development on community wellbeing. Tourism Management, 69, 232-245.

Telfer, D. J., and Sharpley, R. (2008). Tourism and development. London: Routledge

Tosun, C. ve Bilim, Y. (2004). Şehirlerin turistik açıdan pazarlanması: Hatay örneği. Anatolia:Turizm Araştırmaları Dergisi. 15(2),125-138.

Türksoy, S. S. (2016). Sürdürülebilir turizm uygulamaları. (Ed: Nilüfer Koçak). Sürdürülebilir Turizm Yönetimi. Ankara: Detay yayın, 219-283.

Ünlüönen, K., ve Tayfun, A. (2003). Turistlerin yerli halkın tüketim davranışlarına etkileri üzerine ampirik bir araştırma. Muğla Üniversitesi Sosyal Bilimler Enstitüsü Dergisi, 10.

Üstündağll, E., Baybars M. ve Güzeloğlu B. E. (2015). Collaborative sustainability: analyzing economic and social outcomes in the context of cittaslow. Business and Economics Research Journal, 6\1, 125-144.

Vogt, C., Jordan, E., Grewe, N. and Kruger, L. (2016). Collaborative tourism planning and subjective well-being in a small island destination. Journal of Destination Marketing and Management 5, 36-46.

Von Kamp, I., Leidelmeijer, K., Marsman, G. and de Hollander, A. (2003). Urban environmental quality and human wellbeing towards a conceptual framework and demarcation of concepts: a literature study. Landscape and Urban Planning, 6: 5-18.

World Health Organization. (1997). Whoqol: Measuring quality of life world health organization: division of mental health and prevention of substance abuse. Geneva.

Yıldırım, Y. K. ve Fadıloğlu, Ç. (2005). Diyaliz hastalarında progresif gevşeme yöntemlerinin kaygı düzeyi ve yaşam kalitesine olan etkisinin incelenmesi. Ege Üniversitesi Hemşirelik Yüksek Okulu Dergisi, 21 (1), 33- 45.

Zorba, E. (2014). Yaşam kalitesi ve fiziksel aktivite. 10Th. International Sports Sciences Congress, 82-85. Web: http://www.erdalzorba.com/41_ Yasam-Kalitesi-Ve-Fiziksel- Aktivite,-ZORBA-Erdal.html adresinden 01.01. 2020'de alınmıştır. 